\title{
Potential of Small Holder Farmers Agricultural Practices in Enhancing Soil Organic Carbon Stock and Other Selected Soil Physico Properties at Akaki District, Ethiopia
}

\author{
Addisu Wakayo ${ }^{1, \dagger}$, Tokuma Urgessa ${ }^{2, \dagger}$ \\ ${ }^{1}$ Oromia Department of Agriculture and Natural Resource, Bishoftu, Ethiopia \\ ${ }^{2}$ Ethiopian Biodiversity Institute, Addis Ababa, Ethiopia
}

Email address:

Wakayo.adisu@yahoo.com (A. Wakayo), tokeurgessa@gmail.com (T. Urgessa)

\section{To cite this article:}

Addisu Wakayo, Tokuma Urgessa. Potential of Small Holder Farmers Agricultural Practices in Enhancing Soil Organic Carbon Stock and Other Selected Soil Physico Properties at Akaki District, Ethiopia. Agriculture, Forestry and Fisheries.

Vol. 8, No. 6, 2019, pp. 112-120. doi: 10.11648/j.aff.20190806.12

Received: August 20, 2019; Accepted: October 26, 2019; Published: January 6, 2019

\begin{abstract}
Land degradation and extensive use of agricultural lands have led to the decline in soil fertility. To reverse the nutrient deterioration of cultivated lands, farmers have started employing various conservation agriculture practices. This study was initiated to examine the potential of conservation agriculture (integrated practices such as inter cropping, crop rotation, residue retention and minimum tillage) by smallholder farmers to enhance soil organic carbon stock and other selected soil physicochemical properties in Akaki district Bilbilo micro watershed. A systematic sampling method was employed for data collection. Totally 96 composite soil samples ( 8 plots x 2 systems x 2 replication of site $\times 3$ depth: $0-10 \mathrm{~cm}, 10-20 \mathrm{~cm}$ and $20-$ $30 \mathrm{~cm})$ were collected for analysis. Results showed that soil bulk density $(B D)$ was significantly $(\mathrm{p}<0.05)$ varied with practices and depth $(\mathrm{p}<0.001)$. It was lower in soil under conservation $\left(0.78 \mathrm{~g} \mathrm{~m}^{-3}\right)$ than under conventional practice $\left(1.48 \mathrm{gm}^{-3}\right)$; and in the top layer $0-10 \mathrm{~cm}(1.21 \pm 0.05)$ than the rest depths. BD showed increasing trend with soil depth across the practices: lower on the top $0-10 \mathrm{~cm}$ depth $(0.78 \pm 0.03)$ compared with the rest. The $\mathrm{pH}$ was higher (7.28) in conservation than conventional (5.75). The CEC was higher $(14.6 \mathrm{Cmol}(+) / \mathrm{kg})$ in conservation practice than in the conventional $(10.3 \mathrm{cmol}(+) / \mathrm{kg})$. Both pH and CEC had shown increase in the two practices and soil depth due to the leaching of base cation from upper to lower layers. The mean SOC stocks decrease with increasing soil depth about the significant variations with treatments and depth. The SOC stock was higher $(110.6 \mathrm{t} \mathrm{c} / \mathrm{h})$ in conservation practice than in conventional practice $(50.22 \mathrm{t} / \mathrm{ha})$. Similarly, total $\mathrm{N}$ stocks was also higher $(19.5 \mathrm{t} \mathrm{c} / \mathrm{ha})$ in conservation practice than in conventional practice $(17.4 \mathrm{t} \mathrm{c} / \mathrm{ha})$. SOC and total $\mathrm{N}$ in both practices had decreased with soil depth due to lower accumulation of organic residue in the lower layer. Likewise, $\mathrm{C}: \mathrm{N}$ ratios had increases with depth due to similar reason the decrease the amount of soil organic carbon and TN pool (e.g. root biomass) with depth. However, the C: $\mathrm{N}$ ratio has higher value in conservation practice (6.51) than in conventional practice (6.05). Most of the measured soil properties were improved in CA aided followed by soil depth compared with conventional agriculture and at soil depth layers ones. The interaction of farming practice types and soil depth also significantly affected all parameters.
\end{abstract}

Keywords: Nutrient Management, Residue Retention, Crop Rotation, Crop Land Use, Step-wise Integration, Soil Bulk Density

\section{Introduction}

Agricultural activities were responsible for about one third of the world's greenhouse gas (GHG) emissions, especially in developing countries [13]. Certainly, smallholder agricultural systems are highly dynamic and heterogeneous environments that may have significantly contributed to
GHG emissions from the past number of decades [3]. Another direct because of farmer's persistent use of traditional production practices is rapidly increasing production costs agriculture-based technologies for production systems. Furthermore, these systems traditionally suffer from severe soil organic matter (SOM) depletion due to intense decomposition following soil ploughing, consider 
using most of this ground biomass during harvested, and the enhanced soil erosion inherent to those activities [20].

Conservation agriculture has been promoted as an agricultural practice that increases agricultural sustainability, associated with a potential for mitigating greenhouse gas emissions [29]. Therefore, conservation agriculture (CA) aims to conserve, improve and make more efficient use of natural resources through integrated management of available soil, water and biological resources combined with external inputs. It's can also be referred to as resource efficient or resource effective agriculture [14]. In Ethiopia, 85\% of the population was direct supported by the agricultural economy [17].

The residue gradually breaks down in the soil, increasing the amount of organic matter in the soil. However, ploughing damages the soil cultivation leaves the soil bare, exposing it to erosion and water loss through evaporation, which results on the capping of the soil surface, accelerated decomposition of soil organic matter and contributes to the destruction of soil structure.

Repeated ploughing and cultivation at the same depth increases the risk of soil compaction and creation of hardpans at the working depth and mixing of the soil layers can severely harm soil organisms and reduce soil fertility [24]. Since the smallholder farmer, conservation agriculture is enhancing the selected soil physicochemical properties and soil organic carbon stock, this study was initiated to generate scientific evidence on their effectiveness on improving the soil carbon stock and other soil physicochemical properties. This study aims to disclose the potential of small holder farmers' agricultural practices in enhancing soil organic carbon stock and other selected soil physico-properties.

\section{Method and Materials}

\subsection{Description of the Study Area}

The study site was located in the Akaki district of the special zone surrounding Finfinnee, the Oromia region, Ethiopia. It located at $37 \mathrm{~km}$ southeast of Addis Ababa. Geographically, it lies between $8^{\circ} 49^{\prime} 0^{\prime \prime} \mathrm{N}$ and $8^{\circ} 43^{\prime} 30^{\prime \prime} \mathrm{N}$ latitudes and between $38^{\circ} 43^{\prime} 00^{\prime \prime} \mathrm{E}$ and $38^{\circ} 48^{\prime} 30^{\prime \prime} \mathrm{E}$ Longitudes. Akaki district bounded by Ada'a district in the East, Sebeta Hawas and Kersa Malima districts in the West, LibenZukala district in the South and Addis Ababa, Ginbichu and Barak districts in the North $[2,15]$.

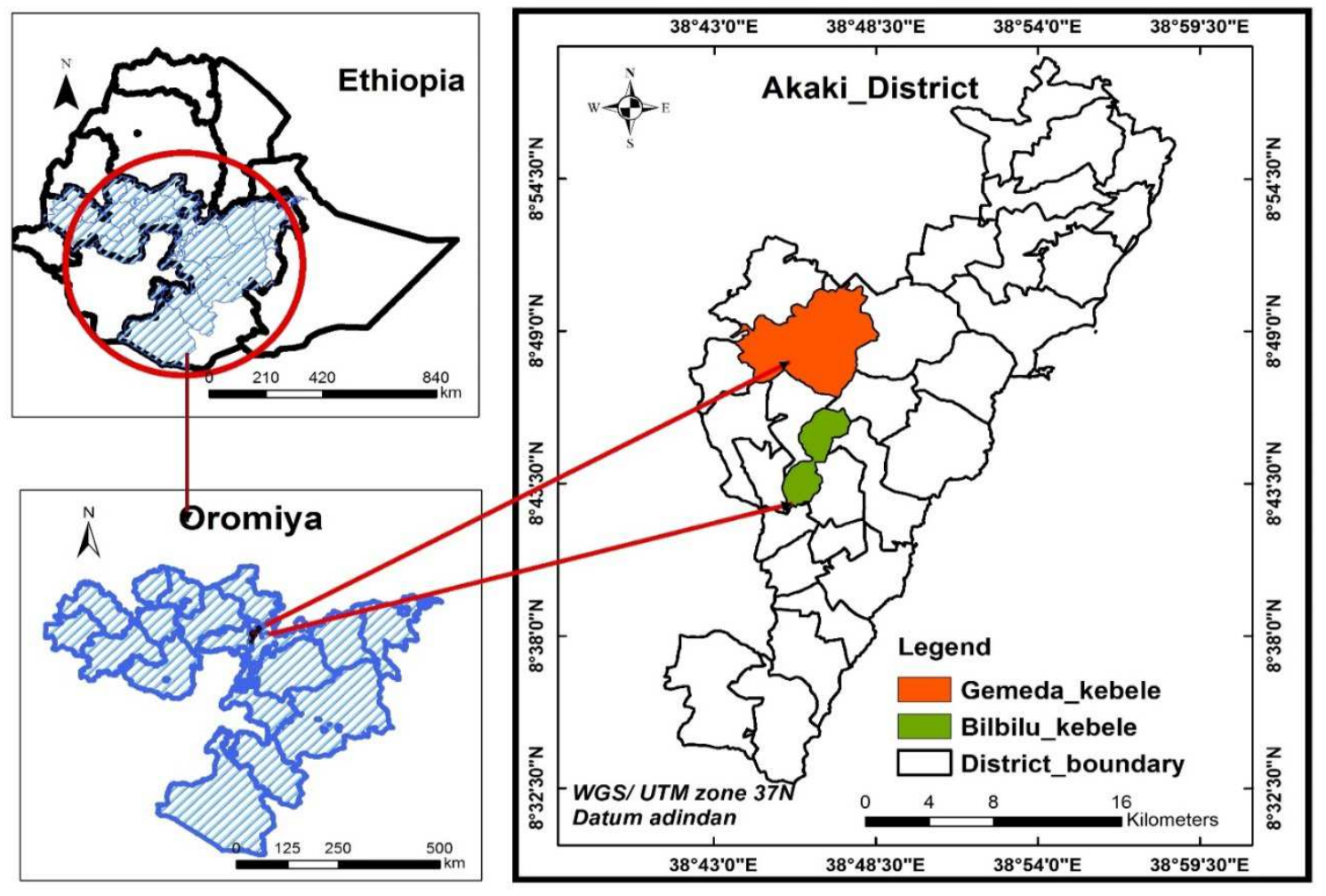

Figure 1. Study site map.

The study sites were selected purposely; since the soil sample was taken from selected site categorized in to CA (10.12ha) identify activities like ( integration of acacia species distribution in farming land, crop rotation, intercropping, minimum tillage and residue retention) and the adjacent of conventional agriculture (10.12ha) where no management practices were applied and freely accessed were used. Criteria for the field site selection were due to recent application of conservation agriculture practice as compared with traditional farming practices.

Since, the conservation and conventional agriculture practices were found adjacent to each other; the Green Foundation of Ethiopia (GEF) and climate resilience green economy (CRGE) of the Bibilo and Gemada kebele 
beginning from 2015 to $2018 \mathrm{GC}$ fund it. The conservation site was the project area supported by CRGE project farmers an integrated agronomical soil and water conservation implemented and conventional agriculture no management practices other farming practice without project area.

\subsubsection{Sample Size Determination}

The numbers of required sample plots were decided using statistical approach as follows:

$$
\mathrm{n}=\frac{(\mathrm{N} * \mathrm{~S})^{2}}{\frac{\mathrm{N}^{2} * \mathrm{D}^{2}}{\mathrm{t} \alpha_{2}}+\mathrm{N} * \mathrm{~S}^{2}}=32 \text { plot }
$$

Where: $\mathrm{n}=$ total number sample plots

$\mathrm{N}=$ Number of sample plots in the study area

$t_{\alpha}=$ Student's $t$ with degrees of freedom at $95 \%$ probability level

$\mathrm{D}=$ are the standard deviation

$\mathrm{S}=$ sample variance

\subsubsection{Soil Sampling Design and Analysis}

Totaling 96 composite soil samples (2 site replicates *2 farming practices $* 8$ sample plots $* 3$ depth) were collected from the specified soil layers $(0-10,10-20$ and 20-30) $\mathrm{cm}$. On average, the soil sample plots were laid at a distance of $80 \mathrm{~m}$ from each plot for both farming practices and $55 \mathrm{~m}$ between the transect. To avoid the effect of disturbances the first and the last transects line were laid at a distance of $150 \mathrm{~m}$ from the edges. Systematic random soil sampling techniques were used from two farming practices. At each site, soil samples were collected from 24 sampling points in February 2018.

Soil samples were collected from two farming practices conservation and conventional agriculture at the specified three soil layers of the four sub-plots of the main plot within each soil layer of the two farming practices. The soil bulk density (Bd) samples were taken for the different depth intervals following the core method [4]. Totally 96 undisturbed soil samples were taken from to determine soil bulk density.

\subsubsection{Soil Laboratory Analysis}

Soil particle size distributions were determined by Bouyoucos hydrometer method [7]. The soil organic C fraction was determining following [27] method. Total nitrogen was analyzed using the Kjeldahl method. Soil $\mathrm{pH}$ was measured potentiometrically in the supernatant $1: 2.5$ soil: liquid mixture of waterusing a $\mathrm{pH}$ meter $\mathrm{pH}-\mathrm{H}_{2} \mathrm{O}$ [25]. Cation exchange capacity was analyzed using Ammonium acetate by [6] method.

The bulk density of 96 of soil samples was oven dried at $105^{\circ} \mathrm{C}$ for 48 hours and the rock fragment correction was done. Soil bulk density of the soil sample was calculated using (equation 2). After the oven dried soil mass identified the rock fragment $(>2 \mathrm{~mm})$ size was again dried for then mass rock fragments and fine soil bulk density was measured [8 and 15].

$$
\text { BD-fine soil }=\frac{\text { Oven dry weight }}{\text { volume sample }-\frac{\text { Weight of rock fraction }}{\text { P rock fragment }}}
$$

Where: $B D=$ Bulk density, $P=$ a rock fragment mass $(\rho$ rock fragments) of $2.65 \mathrm{~g} / \mathrm{cm}^{3}$ [10]. In the laboratory the soil was air-dried and weighed. A sub sample was then ovendried, and gravimetric water content was calculates to establish the oven-dried weight of the total sample.

\subsubsection{Soil Organic Carbon and Total Nitrogen Stock Estimation}

The soil organic carbon and $\mathrm{TN}$ by volume $\left(\mathrm{C} \mathrm{kg} \mathrm{m}^{-2}, \mathrm{~N}\right.$ $\mathrm{kg} \mathrm{m}^{-2}$ ) for individual profile soil layers was calculated using (equations 3 and 4).

$$
\begin{gathered}
\mathrm{SOC} \mathrm{d} /\left(\mathrm{kg} / \mathrm{m}^{2}\right)=100 \times\left(\mathrm{OC}_{\mathrm{i}} \times \mathrm{Bd}_{\mathrm{i}} \times \mathrm{D}_{\mathrm{i}} \times\left(1-\mathrm{p}_{\mathrm{i}}\right)\right. \\
\mathrm{TN} \mathrm{d} /\left(\mathrm{kg} / \mathrm{m}^{2}\right)=100 \times\left(\mathrm{TN}_{\mathrm{i}} \times \mathrm{Bd}_{\mathrm{i}} \times \mathrm{D}_{\mathrm{i}} \times\left(1-\mathrm{p}_{\mathrm{i}}\right)\right.
\end{gathered}
$$

Where: SOCd is the Soil organic carbon density, STNd is the soil total nitrogen density $\left(\mathrm{kg} \mathrm{m}^{2}, \mathrm{~N} \mathrm{~kg} \mathrm{~m}^{2}\right)$, Bdi is the bulk density of layer i, OCi is the concentration of organic carbon (C\%) in layer $\mathrm{i}, \mathrm{Di}$ is the thickness of this layer $(\mathrm{cm})$, and $\mathrm{p}_{\mathrm{i}}$ is the volume of the fraction of fragments $>2 \mathrm{~mm}$.

Since the soil, particles were mostly above $2 \mathrm{~mm}$, this fragment fraction was calculate by (equation 2). Soil organic carbon stocks ( $\mathrm{t} / \mathrm{ha}$ ) were primarily calculated by multiplying measured soil organic carbon (SOC) values $\left(\mathrm{g}\right.$ soil $\left.^{-1}\right)$ with bulk density $\left(\mathrm{g} / \mathrm{cm}^{-}{ }^{3}\right)$ and the depth of the sampled soil and also expressed in $\mathrm{kg}$ per $\mathrm{mg}$ of soil. The SOC $\left(\mathrm{kg} \mathrm{m}^{-2}\right)$ density was calculate [23]. The representative values of the soil organic carbon density were average and converted to soil organic carbon stock in tons per hectare ( $\mathrm{t} \mathrm{C}$ ha-1) for each farming practices.

The soil carbon stock was calculated using the equation.

$$
\begin{gathered}
\text { SCS }=\frac{\text { SOCd } * \text { test crop Area })}{100} \\
\text { TNS }=\frac{\text { STNd } *(\text { test crop Area })}{100} \\
\text { SCS (total) }=\sum \mathrm{SCS} \\
\text { TNS (total) }=\sum \mathrm{TNS}
\end{gathered}
$$

Where: SCS is the soil carbon stocks (T/ha) or TNS is the total nitrogen stocks (T/ha), SOCd is the soil organic carbon density $\left(\mathrm{kg} / \mathrm{m}^{2}\right)$ or STNd is the soil total nitrogen density $\left(\mathrm{kg} / \mathrm{m}^{2}\right)$. (Area) were the SOC or TNS stock (Tons/ha), the SOC or TN density $\left(\mathrm{kg} / \mathrm{m}^{2}\right)$ and the area $\left(\mathrm{m}^{2}\right)$ for agricultural land of each farming practices situation. SCS or TNS was the sum of the SOC or TN Sock of all land cover types at layer $(0-10 \mathrm{~cm}, 10-20 \mathrm{~cm}$ and $20-30 \mathrm{~cm})$.

Soil organic carbon stock or TN stock each layer of the dominant $\mathrm{CA}$ and conventional agriculture was calculated by multiplying the SOC or TN density obtained from equation 3 by the total area covered by a particular farming practices. Subsequently, SOC density or TN density in each soil layer thickness was summed up to determine soil organic $\mathrm{C}$ and TN stock contained up to $30 \mathrm{~cm}$ depth for each farming practices. 


\subsection{Statistical Analysis}

The soil carbon stocks and other selected soil physicochemical properties were subject to analysis of using (SAS. V. 9.3, SPSS 23 version) software program. Two-way ANOVA was employed by ' $t$ ' independent method, to analyze the interaction effects and mean values of selected soil properties within and among the two farming practice types and three soil depth at $\mathrm{p}<0.05$ significance level. Test for normality by similar to Shapiro-wilk of the distribution of all dependent data was verified prior to analysis. All statistical analyses were performed at $\mathrm{P} \leq 0.05$.

\section{Results and Discussion}

\subsection{Soil Physical Properties}

\section{Soil Particle Fractions and Bulk Density}

The soil textural class across the farming practices was clay (Table 1), indicating that the inherent property was originated from the same parent material. The result showed that the dominant clay mineral of the vertisols in the study area.

The fact from the result showed that soil bulk density (Bd) varied significantly with treatments, depths and the interaction effects $(\mathrm{p}<0.0001$, Table 2$)$. It was lower in soil under conservation $\left(0.78 \mathrm{~g} / \mathrm{cm}^{3}\right)$ in the top $(0-10 \mathrm{~cm})$ surface soil than in the rest of the depths under the CA and conventional practice (Table 1).

The soil Bd showed an increasing tendency with depth across the treatments (Table 1), Soil Bd at bottom layers of conventional agriculture increased by $47.29 \%$ as compared to the conservation agriculture (Table 1). In conventional agriculture, the bulk density at $0-10 \mathrm{~cm}$ soil layer was higher (35.53\%) than the $0-10 \mathrm{~cm}$ soil depth as well as in the conservation agriculture. Whereas, the conventional agriculture, the $\mathrm{Bd}$ of the soil layer, $20-30 \mathrm{~cm}$ was significantly $(\mathrm{P}<0.05)$ higher $(24.32 \%)$ than in that of the soil depth $20-30 \mathrm{~cm}$ conservation agriculture (Table 1).

The main effect, of conventional agriculture was also significantly $(\mathrm{P}<0.05)$ higher $\left(1.34 \mathrm{~g} / \mathrm{cm}^{3}\right)$ than $\mathrm{CA}(0.95$ $\mathrm{g} / \mathrm{cm}^{3}$ ) (Table 1). In terms of the soil depth, the highest Bd $\left(1.48 \mathrm{~g} / \mathrm{cm}^{3}\right)$ was recorded at the lower soil depth $(20-30 \mathrm{~cm})$ under conventional agriculture higher than the bottom layers $(20-30 \mathrm{~cm})$ conservation agriculture $\left(1.12 \mathrm{~g} / \mathrm{cm}^{3}\right)($ Table 1$)$.

The mean bulk density for total depth $0-30 \mathrm{~cm}$ across the two farming practice was increased from $0.95 \mathrm{~g} / \mathrm{cm}^{3}$ under conservation agriculture to $1.34 \mathrm{~g} / \mathrm{cm}^{3}$ in conventional agriculture. However, the $\mathrm{Bd}$ in the $\mathrm{CA}$ was significantly $(\mathrm{P}<0.05)$ lower as compared with conventional agriculture across the farming practices and vertical soil profile.

Table 1. Soil te $\times$ tural fractions and soil bulk density $(B d)$ in relation to farming practice and soil depths.

\begin{tabular}{llll}
\hline \multirow{2}{*}{ Variables } & Depth (cm) & Farming practice type & Conventional Agriculture \\
\cline { 2 - 4 } & $0-10$ & Conservation Agriculture & $25.6 \pm 3^{\mathrm{a}}$ \\
Sand (\%) & $10-20$ & $16 \pm 4^{\mathrm{b}}$ & $24 \pm 5^{\mathrm{a}}$ \\
& $20-30$ & $21 \pm 6^{\mathrm{b}}$ & $26 \pm 8^{\mathrm{b}}$ \\
& Overall & $17 \pm 4^{\mathrm{c}}$ & $25 \pm 5.3^{\mathrm{a}}$ \\
& $0-10$ & $18 \pm 4.6^{\mathrm{b}}$ & $28 \pm 6^{\mathrm{a}}$ \\
Silt (\%) & $10-20$ & $24 \pm 4^{\mathrm{b}}$ & $26 \pm 6^{\mathrm{a}}$ \\
& $20-30$ & $25 \pm 5^{\mathrm{b}}$ & $25 \pm 7^{\mathrm{b}}$ \\
& Overall mean & $30 \pm 11^{\mathrm{a}}$ & $26 \pm 6.3^{\mathrm{b}}$ \\
& $0-10$ & $26.4 \pm 6.6^{\mathrm{b}}$ & $47 \pm 9^{\mathrm{b}}$ \\
Clay (\%) & $10-20$ & $60 \pm 4^{\mathrm{a}}$ & $50 \pm 7^{\mathrm{b}}$ \\
& $20-30$ & $54 \pm 6^{\mathrm{b}}$ & $50 \pm 12^{\mathrm{bc}}$ \\
& Overall mean & $53 \pm 12^{\mathrm{b}}$ & $49 \pm 9.3^{\mathrm{c}}$ \\
Bd (g/cm3) & $0-10$ & $55.6 \pm 7.3^{\mathrm{b}}$ & $1.21 \pm 0.05^{\mathrm{d}}$ \\
& $10-10$ & $0.78 \pm 0.03^{\mathrm{c}}$ & $1.35 \pm 0.04^{\mathrm{b}}$ \\
& $20-30$ & $0.95 \pm 0.05^{\mathrm{b}}$ & $1.48 \pm 0.04^{\mathrm{a}}$ \\
TL & Overall mean & $1.12 \pm 0.13^{\mathrm{ab}}$ & $1.34 \pm 0.04^{\mathrm{b}}$ \\
& $0-10$ & $0.95 \pm 0.07^{\mathrm{b}}$ & $C^{\mathrm{b}}$ \\
& $10-20$ & Clay & Clay $^{\mathrm{b}}$ \\
& $20-30$ & Clay & Clay \\
\hline
\end{tabular}

Similar superscript letters were shown in the column for the same parameter indicate no significant difference at 0.05 where, $\mathrm{Bd}=\mathrm{Bulk}$ density $\left(\mathrm{g} / \mathrm{cm}^{3}\right)$, $\mathrm{TL}=\mathrm{Te} \times$ tural class.

Table 2. Two-way ANOVA results for soil bulk density and soil te $\times$ ture.

\begin{tabular}{|c|c|c|c|c|c|c|c|c|c|}
\hline \multirow{2}{*}{$\begin{array}{l}\text { source of } \\
\text { variation }\end{array}$} & \multirow{2}{*}{ DF } & \multicolumn{2}{|c|}{ Sand (\%) } & \multicolumn{2}{|c|}{ Silt (\%) } & \multicolumn{2}{|c|}{ Clay (\%) } & \multicolumn{2}{|c|}{ BD (g/cm3) } \\
\hline & & MS & $\mathbf{P}$ & MS & $\mathbf{P}$ & MS & $\mathbf{P}$ & MS & $\mathbf{P}$ \\
\hline FP & 1 & 5.3 & 0.216 & 3.39 & 0.0235 & 1.47 & $<.0001$ & 0.292 & $<.0001$ \\
\hline $\mathrm{D}$ & 2 & 3.18 & 0.398 & 4.3 & 0.5102 & 0.58 & $<.0001$ & 0.155 & $<.0001$ \\
\hline $\mathrm{FP} \times \mathrm{D}$ & 2 & 11.48 & 0.039 & 1.57 & 0.1834 & 0.02 & 0.0457 & 0.04 & $<.0001$ \\
\hline Error & 89 & 3.41 & & 63.9 & & 0.0057 & & 0.0028 & \\
\hline
\end{tabular}

DF Degree of freedom, FP Farming practice, D soil depth, SE standard error of the mean

The similarity in textural class with the two farming practices shows the fewest impacts of the on the soil forming 
processed as parent materials could not be changed shortly, since the duration of the agricultural practices was four years. Thus, was in line with [5] in which the textural class of a soil did not change by the management practice.

The highest soil bulk density of the conventional agriculture could be due to land degradation; high soil erosion and compaction of soil particles as resulting in higher bulk densities reduce soil fertility. However, the fine soil particle has transported by soil erosion and compaction by livestock's.

In line with this study, [22] reported that the bulk density of vertisols varies greatly from their swelling and shrinking nature with changes in soil moisture content. Similarly, [22] added that the soils have high bulk density when these are dry and low values when in a swollen stage. Such as variations at the lower end of $\mathrm{BD}$ are more than at the highly ending of $\mathrm{BD}$ because low $\mathrm{BD}$ is associates with organic soils (high $\mathrm{C}$ org) and a change from say, 0.78 to $1.48 \mathrm{~g} / \mathrm{cm} 3$ leads to a doubling of SOC stock and mass. The highest bulk densities was due to the land degradation and high soil erosion for compaction of soil particles as resulting of higher bulk densities of conventional practices [24].

Similarly, from Tanzania, Kenya, and Zimbabwe, reported that there was a significant difference in soil bulk density under conservation farming practice than conventional agricultural practices within four years practices $[11,19,13]$. So based on these findings, the soil bulk density may be affected or changed after practicing conservation agriculture at four years' of duration.

\subsection{Soil Chemical Properties}

\subsubsection{Soil pH $\left(\mathrm{H}_{2} \mathrm{O}\right)$ and $\mathrm{CEC}$}

The results showed that the mean values of $\mathrm{pH}\left(\mathrm{H}_{2} \mathrm{O}\right)$ were significant at $(\mathrm{p}<0.05)$ from the two farming practice and in all soil layers (Table 3 ). Similarly, the $\mathrm{pH}$ of the $\mathrm{CA}$ in all soil layers $(0-10,10-20$ and $20-30 \mathrm{~cm})$ was higher by $24.42 \%$, $21.82 \%$ and $17.23 \%$ than the conventional agriculture at the same soil layers (Table 3 ).

Together, the higher mean value of $\mathrm{pH}$ was recorded in $\mathrm{CA}$ by the variation in $8.38 \%$ to $34.63 \%$ at the middle soil layers $(10-20 \mathrm{~cm})$ and lower soil layer $(20-30 \mathrm{~cm})$ respectively.

This study indicated that the mean values of $\mathrm{pH}$ under $\mathrm{CA}$ were at $\mathrm{P}<0.05$ significant higher (7.28) than the mean values of the conventional agriculture (5.75) and the highest mean value of $\mathrm{pH}$ was recorded at the lower soil layers (Table 3).

Table 3. Soil chemical properties in relation to farming practice and soil depths.

\begin{tabular}{llll}
\hline \multirow{2}{*}{ Variables } & Depth $(\mathbf{c m})$ & Farming practice type & \\
\cline { 3 - 4 } & $0-10$ & Conservation Agriculture & Conventional Agriculture \\
\hline & $10-20$ & $6.92 \pm 0.58^{\mathrm{a}}$ & $5.23 \pm 0.45^{\mathrm{c}}$ \\
$\mathrm{pH}\left(\mathrm{H}_{2} \mathrm{O}\right)$ & $20-30$ & $7.33 \pm 0.10^{\mathrm{b}}$ & $5.73 \pm 0.53^{\mathrm{d}}$ \\
& Overall mean & $7.6 \pm 0.20^{\mathrm{a}}$ & $6.29 \pm 0.65^{\mathrm{b}}$ \\
& $0-10$ & $7.28 \pm 0.29^{\mathrm{ab}}$ & $5.75 \pm 0.54^{\mathrm{abc}}$ \\
& $10-20$ & $13.12 \pm 0.99^{\mathrm{b}}$ & $8.50 \pm 2.84^{\mathrm{d}}$ \\
$\mathrm{CEC}(\mathrm{Cmol} / \mathrm{kg})$ & $20-30$ & $14.28 \pm 1.09^{\mathrm{b}}$ & $9.99 \pm 2.16^{\mathrm{c}}$ \\
& Overall mean & $16.4 \pm 1.67^{\mathrm{a}}$ & $11.92 \pm 3.28^{\mathrm{ab}}$ \\
& $14.6 \pm 1.66^{\mathrm{b}}$ & $10.13 \pm 2.76^{\mathrm{c}}$ \\
\hline
\end{tabular}

Overall means within rows and columns followed by the same letter are not statically different at $\mathrm{p} \leq 0.05$ with respect to soil depth and farming practice,

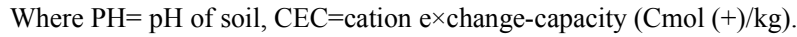

The mean values of CEC under CA increased by $27.31 \%$ than conventional agriculture. Similarly, it increased by $35.21 \%$, $30.04 \%$ and $27.31 \%$ under the soil depth $0-10,10-20$ and $20-$ $30 \mathrm{~cm} \mathrm{CA}$ then conventional agriculture (Table 3). Moreover, the higher mean values of CEC were recorded at in all soil layer (0$10,10-20$ and $20-30 \mathrm{~cm}$ ) of the CA than the conventional agriculture of the same soil layers, respectively (Table 3).
Consequently, the main effect of the two farming practices (conservation and conventional agriculture) on CEC was significant.i.e.; the CEC of the CA was greater than the CEC of conventional agriculture by $30.61 \%$. Likewise, the CEC was to show increments significant $(\mathrm{p}<0.05 \%)(13.12 \mathrm{Cmol}(+) / \mathrm{kg}$, $14.28 \mathrm{Cmol}(+) / \mathrm{kg}, 16.4 \mathrm{Cmol}(+) / \mathrm{kg})$ with the increase in the soil layer (0-10, 10-20 and 20-30 cm) (Table 3).

Table 4. Two-way ANOVA results for soil $p H$ and CEC.

\begin{tabular}{llllll}
\hline \multirow{2}{*}{ source of variation } & \multirow{2}{*}{$\mathbf{D F}$} & $\mathbf{P H}\left(\mathbf{H}_{\mathbf{2}} \mathbf{O}\right)$ & \multicolumn{3}{c}{$\mathbf{C E C}(\mathbf{C m o l}(+) / \mathbf{k g})$} \\
\cline { 3 - 6 } & & $\mathbf{M S}$ & $\mathbf{P}$ & $\mathbf{M S}$ & $\mathbf{P}$ \\
\hline FP & 1 & 12.8 & $<.0001$ & 29.91 & $<.0001$ \\
$\mathrm{D}$ & 2 & 6.82 & $<.0001$ & 3.37 & $<.0001$ \\
$\mathrm{FP} \times \mathrm{D}$ & 2 & 11.1 & 0.0304 & 0.24 & 0.0352 \\
Error & 89 & 0.005 & & 5.31 & \\
\hline
\end{tabular}

DF, Degree of freedom, FP farming practiced, D soil depth, SE standard error of the mean, MS Mean square, PH soil pH or soil reaction, CEC, Cation exchange capacity.

The soil $\mathrm{pH}$ of conventional practice was generally lower from the early stages of management than conservation agricultural. This study is in line with $[10 ; 1 ; 9]$ in which lower soil $\mathrm{pH}$ was $\mathrm{e} \times$ hibited in conventional practice than the conservation practices. Such a result might be attributed to the depletion of organic matter in intensive cultivation/ 
conventional agriculture. [20] also added that root respiration and decomposition of organic matter produces carbon dio $\times$ ide, which reacts and forms a weak acid, carbonic acid, and this can be a contributing factor to soil acidification in conventional agriculture farming practices.

The higher CEC record in CA than the conventional agriculture could be due to the higher root biomass production of crop species and retention of crop residue on the soil surface that caused build-up of organic carbon responsible for greater CEC under conservation agriculture system. This study is in line with studies by [26;28] also reported the higher the CEC in CA than the conventional agriculture. Similarly reported by [18] also reported increase the CEC in upper layers of soil the residue raised as compared residues was removed farming practice. Similarly, [18] also reported that increase the CEC in upper layers of soil the residue raised as compared residues was removed farming practice that attributed to the presence of high soil carbon content.

\subsubsection{Soil Organic Carbon and TN Content}

The mean values of soil organic $\mathrm{C}$ and TN content of the soils showed much variation among the two farming practices and soil depth (Table 5). The soil organic $\mathrm{C}$ and TN content of upper soil layers $(0-10 \mathrm{~cm})$ of the conservation agriculture (CA) increases by $36.3 \%$ and $43.75 \%$ as compared to soil layers (0-10) of conventional agriculture practices (Table 5).
Similarly, the soil organic carbon and TN content in CA under $20-30 \mathrm{~cm}$ soil depth increased by $28.39 \%$ and $9.09 \%$ as compared with $20-30 \mathrm{~cm}$ soil depth of conventional agriculture.

With further variability $(11.21 \%$ to $27.97 \%)$ was recorded at the top soil layer $(0-10 \mathrm{~cm})$ of the two farming practices (conservation and conventional agriculture) with the lower range of soil disturbance in conservation agriculture and higher range of soil disturbance in the conventional agriculture.

It was higher SOC and TN content $(1.68 \%, 0.32 \%) 0-10 \mathrm{~cm}$ at soil layers, and the lower $(1.07 \%, 0.18 \%)$ at $0-10 \mathrm{~cm}$ of CA and conventional agriculture (Table 5). With increasing the soil depth, both SOC and TN were decreased in both farming practice (conservation and conventional agriculture); while, the SOC and TN in conservation agriculture (CA) was higher than in the conventional agriculture. It is also clearly visible that as the soil depth increases the SOC and TN content decreased continuously in both farming practices (Table 5). Soil organic C concentration in the total soil layers was higher $(1.19 \%)$ in $\mathrm{CA}$ than the conventional agriculture $(0.78 \%)$ at $\mathrm{P}<0.05$ significant.

An overall total $\mathrm{N}$ for the $\mathrm{CA}$ was increased by $35 \%$ higher than the conventional agriculture at significant $(\mathrm{P}<0.05)$ (Table 6). An effect of farming practices by soil depth of TN was significantly higher $(0.32 \%)$ at $0-10 \mathrm{~cm}$ surface layer of the conservation higher than in the surface of the conventional agriculture $(0.10 \%)$ (Table5). The higher (1.68\%) SOC was recorded at the top soil layer of the CA than the conventional agriculture $(0.72 \%)$.

Table 5. Soil chemical properties in relation to the farming practice and soil depths.

\begin{tabular}{llll}
\hline \multirow{2}{*}{ Variable } & Depth $(\mathbf{c m})$ & Farming practice type & Conventional Agriculture \\
\cline { 3 - 4 } & $0-10$ & Conservation Agriculture & $1.07 \pm 0.12^{\mathrm{b}}$ \\
SOC (\%) & $10-20$ & $1.68 \pm 0.47^{\mathrm{a}}$ & $0.72 \pm 0.09^{\mathrm{c}}$ \\
& $20-30$ & $0.81 \pm 0.22^{\mathrm{b}}$ & $0.58 \pm 0.12^{\mathrm{d}}$ \\
& Overall mean & $1.19 \pm 0.31^{\mathrm{c}}$ & $0.78 \pm 0.11^{\mathrm{a}}$ \\
& $0-10$ & $0.32 \pm 0.04^{\mathrm{b}}$ & $0.18 \pm 0.03^{\mathrm{c}}$ \\
TN (\%) & $10-20$ & $0.17 \pm 0.03^{\mathrm{b}}$ & $0.13 \pm 0.02^{\mathrm{c}}$ \\
& $20-30$ & $0.11 \pm 0.01^{\mathrm{ab}}$ & $0.10 \pm 0.02^{\mathrm{d}}$ \\
& Overall mean & $0.2 \pm 0.02^{\mathrm{a}}$ & $0.13 \pm 0.023^{\mathrm{a}}$ \\
$\mathrm{C}: \mathrm{N}$ & $0-10$ & $6.23 \pm 2.7^{\mathrm{c}}$ & $5.5 \pm 2.5^{\mathrm{cb}}$ \\
& $10-20$ & $6.38 \pm 1.01^{\mathrm{b}}$ & $6.04 \pm 1.3^{\mathrm{ba}}$ \\
& $20-30$ & $6.93 \pm 2.4^{\mathrm{a}}$ & $6.62 \pm 1.23^{\mathrm{ab}}$ \\
\hline
\end{tabular}

Overall means within rows and columns followed by the same letter are not statically different at $\mathrm{p} \leq 0.05$ with respect to soil depth and farming practice, Where $\mathrm{SOC}=$ soil organic carbon content $(\%), \mathrm{TNC}=$ total nitrogen content $(\%), \mathrm{C}: \mathrm{N}=$ carbon to nitrogen ratios.

The increasing result of SOC and TN in CA was consistent with another study that indicated SOC as affected by conservation agriculture within four years of practice when compared to conventional agriculture. Similarly [21] reported higher plant biomass production leading to large amounts of root residues left in the system and a lower rate of organic matter decomposition due to minimum soil disturbance. In addition, [13] reported higher SOC concentrations in surface soils under $\mathrm{CA}$ as compared to conventional agriculture of northwestern India.

In line, [6] reported that adding more $\mathrm{N}$ fertilizer increase total amount of crops; hence, production of more field biomass that has been also lead to more addition of $\mathrm{C}$ contents with the higher $\mathrm{N}$ level to the soil through more crop residues and a larger root biomass. Inline, [12] also reported that increases in total $\mathrm{N}$ had been measured with increasing additions of crop residue. Similarly, reported with increasing [18] also added reported that the amount of straw retained under permanent raised cropland increased total N. Following the rating of total $\mathrm{N}$ of $>1 \%$ as very high, 0.5 to $1 \%$ high, 0.2 to $0.5 \%$ medium, 0.1 to $0.2 \%$ low and $<0.1 \%$ as very low $\mathrm{N}$ status as indicated by [29] conservation agriculture practices with the soil depth layers have medium content of total $\mathrm{N}$.

\subsection{Carbon-nitrogen Ratio}

The mean value of $\mathrm{C}: \mathrm{N}$ at $20-30 \mathrm{~cm}$ layer of the soil of 
conventional agricultural was significant $(\mathrm{p}<0.05)$ lower than in the $20-30 \mathrm{~cm}$ of conservation agriculture (CA) (Table 6). Mean value of $\mathrm{C}$ : $\mathrm{N}$ ratios in the CA increased by $4.47,5.32$ and $11.71 \%$ than the conventional agriculture at the soil layers: 0-10, 10-20 and 20-30 cm (Table 5). C: $\mathrm{N}$ ratio of surface and subsurface layers increases with depth, with values ranging from 6.62 to 6.93 at $20-30 \mathrm{~cm}$ soil layer and 6.04 to 6.38 at soil layers $10-20$ and 5.5 to 6.23 at soil layer $0-10 \mathrm{~cm}$ in both conventional and conservation agriculture respectively (Table 5). At depths of $0-10,10-20$ and $20-30 \mathrm{~cm}$ the $\mathrm{C}$ : $\mathrm{N}$ ratio was greater conservation agriculture (CA) then under conventional agriculture due to influence by management practices. The $\mathrm{C}$ :
$\mathrm{N}$ ratio was highly variable, especially lower in the soil depth due to influenced soil disturbed by cultivation. The $\mathrm{C}$ : $\mathrm{N}$ ratio differed between $\mathrm{CA}$ and conventional agriculture at any soil depth. Mean $\mathrm{C}$ : $\mathrm{N}$ ratios in vertical soil depth was significantly the agricultural practice increases with increase soil depth in the lower layers of soil depth $20-30 \mathrm{~cm}$ increases than the upper layer soil profile at significance level (Table 5). The C: $\mathrm{N}$ showed an increasing tendency with depth across the treatments (Table 5), C: $\mathrm{N}$ an overall soil layers of conservation agriculture increased by $7 \%$ as compared to the conventional agriculture (Table 5).

Table 6. Two-way ANOVA results for soil SOC, TN and C: $N$.

\begin{tabular}{llllllll}
\hline \multirow{2}{*}{ Source of variation } & \multirow{2}{*}{$\mathbf{D F}$} & SOC (\%) & TN (\%) & & C: $\mathbf{~}$ \\
\cline { 2 - 8 } & & MS & P & MS & P & MS & P \\
\hline FP & 1 & 3.2599 & $<.0001$ & 11.75 & $<.0001$ & 309.5 & $<.0001$ \\
D & 2 & 3.1848 & $<.0001$ & 5.483 & $<.0001$ & 92.34 & $<.0001$ \\
FP $\times$ D & 2 & 0.0372 & 0.048 & 0.856 & 0.043 & 0.66 & 0.046 \\
Error & 89 & 0.0548 & & 0.026 & & 5.423 & \\
\hline
\end{tabular}

$\mathrm{DF}=$ Degree of freedom, $\mathrm{SE}$ standard error of the mean, $\mathrm{FP}=$ farming practice, $\mathrm{D}=$ soil depth, $\mathrm{MS}=\mathrm{Mean}$ square, $\mathrm{SOC}=$ soil organic carbon content, $\mathrm{TN}=\mathrm{Total}$ nitrogen content, $\mathrm{C}: \mathrm{N}=$ carbon to nitrogen ratios.

The relatively narrow range of soil organic $\mathrm{C}$ : $\mathrm{N}$ throughout the soil profile and its general increases with depth. The ration $\mathrm{C}$ : $\mathrm{N}$ in conservation agriculture, soil was slightly higher than conventional agriculture soils. However, due to $\mathrm{C}$ : $\mathrm{N}$ lower in conventional agriculture affects the decreasing of $\mathrm{N}$ pool.

However, conventional agriculture mono cropping was probably, caused by larger root biomass that might have been, exposed to drier soil by rapid soil water uptake throughout the year each time available. The observed values of $\mathrm{C}$ : $\mathrm{N}$ ratios may suggest that there was no $\mathrm{N}$ immobilization, which could significantly affect the availability of $\mathrm{N}$ for crop uptake.

Estimation of Soil Organic Carbon and Total Nitrogen Stock

The mean values of soil organic carbon and Total $\mathrm{N}$ stocks of the soil showed significant variation across sampled farming practices and in all soil depths (Table 7).

The average differences in soil carbon stocks in CA and conventional agriculture in the soil depth $0-10 \mathrm{~cm}$ layer varied between $37.59 \mathrm{CT} / \mathrm{ha}$ and $1.54 \mathrm{NT} / \mathrm{ha}$ whereas, the average difference in soil depth $20-30 \mathrm{~cm}$ soil carbon stock varied from $27.52 \mathrm{CT} /$ ha and $2.39 \mathrm{NT} / \mathrm{ha}$. This means the carbon concentration the mean of SOC and TN stocks decreases with increasing soil depth for both $\mathrm{CA}$ and conventional agriculture treatments.

The carbon stock was a conservation agriculture for the $0-10 \mathrm{~cm}$ depth layers significantly $(\mathrm{p}<0.05)$ higher than conventional agriculture for the $0-10 \mathrm{~cm}$ soil depth layers. The SOC stock in all soil layers $(0-10,10-20$, and $20-30 \mathrm{~cm})$ were also higher by $47.61 \%, 57.75 \%$ and $61.15 \%$ than in the conventional agriculture of the same soil layer at $(\mathrm{P}<0.05)$ significant level.

Table 7. SOC and TN stocks in relation to the farming practice and soil depths.

\begin{tabular}{llll}
\hline \multirow{2}{*}{ Variables } & Depth (cm) & Farming practice type & Conventional Agriculture \\
\cline { 2 - 3 } & $0-10$ & Conservation Agriculture & $69.83 \pm 1.55^{\mathrm{c}}$ \\
SOC stock $(\mathrm{T} / \mathrm{ha})$ & $10-20$ & $133.3 \pm 37.6^{\mathrm{a}}$ & $46.22 \pm 1.84^{\mathrm{b}}$ \\
& $20-30$ & $109.4 \pm 26.7^{\mathrm{bc}}$ & $34.61 \pm 2.39^{\mathrm{d}}$ \\
& Overall mean & $89.1 \pm 27.5^{\mathrm{c}}$ & $50.22 \pm 0.79^{\mathrm{a}}$ \\
& $0-10$ & $110.6 \pm 7.65^{\text {ad }}$ & $6.86 \pm 0.24^{\mathrm{b}}$ \\
SOC density $\left(\mathrm{kg} / \mathrm{m}^{2}\right)$ & $10-20$ & $13.1 \pm 3.5^{\mathrm{a}}$ & $4.54 \pm 0.12^{\mathrm{c}}$ \\
& $20-30$ & $10.75 \pm 2.4^{\mathrm{b}}$ & $3.4 \pm 0.15^{\mathrm{d}}$ \\
& Overall mean & $8.76 \pm 2.5^{\mathrm{c}}$ & $4.9 \pm 0.17^{\mathrm{a}}$ \\
& $0-10$ & $10.87 \pm 3.6^{\mathrm{ab}}$ & $20.27 \pm 2.6^{\mathrm{a}}$ \\
TN stock $(\mathrm{T} / \mathrm{ha})$ & $10-20$ & $27.03 \pm 3.24^{\mathrm{a}}$ & $16.72 \pm 1.3^{\mathrm{b}}$ \\
& $20-30$ & $17.65 \pm 2.44^{\mathrm{b}}$ & $15.22 \pm 1.7^{\mathrm{c}}$ \\
& Overall mean & $13.83 \pm 3.10^{\mathrm{c}}$ & $17.4 \pm 1.86^{\mathrm{ab}}$ \\
& $0-10$ & $19.5 \pm 2.92^{\mathrm{ac}}$ & $0.86 \pm 0.14^{\mathrm{d}}$ \\
TN density $\left(\mathrm{kg} / \mathrm{m}^{2}\right)$ & $10-20$ & $2.48 \pm 0.3^{\mathrm{a}}$ & $0.54 \pm 0.12^{\mathrm{b}}$ \\
& $20-30$ & $1.62 \pm 0.22^{\mathrm{b}}$ & $0.4 \pm 0.15^{\mathrm{c}}$ \\
& Overall mean & $1.27 \pm 0.3^{\mathrm{c}}$ & $0.6 \pm 0.13^{\mathrm{d}}$ \\
\hline
\end{tabular}

Similar superscript letters shown in the column for the same parameter indicate no significant difference, not significant at 0.05 . SOCd, soil organic carbon Density $\left(\mathrm{kg} / \mathrm{m}^{2}\right)$ SOCS, soil organic carbon stocks $(\mathrm{T} / \mathrm{ha})$, TNd, total nitrogen density $\left(\mathrm{kg} / \mathrm{m}^{2}\right)$, TNS, total nitrogen Stocks $(\mathrm{T} / \mathrm{ha})$. 
In terms, of the main effect of the farming practices, soil organic carbon and total $\mathrm{N}$ stocks were $110.6 \mathrm{CT} / \mathrm{ha}$ and $19.5 \mathrm{NT} / \mathrm{ha}$ under conservation and conventional agriculture practices respectively (Table 7). Whereas, conventional agriculture 50CT/ha and 17.4 NT/ha the comparison between the management system (Table 7) showed a significant decrease in the SOC stocks of conventional agriculture. Among the two farming practices and soil depths, the lowest mean soil organic carbon stock $(0.58 \%$ or $34.61 \mathrm{t} / \mathrm{ha})$ in the lower layer of conventional agriculture and the highest SOC stock $(1.68 \%$ or $133.3 \mathrm{CT} / \mathrm{ha})$ at the upper soil layer of conservation agriculture practice was recorded (Table 7). The soil organic carbon and TN stock was showed a decreasing tendency with depth across the treatments at significantly $(\mathrm{P}<0.05)$ (Table 7).

Table 8. Two-way ANOVA results for soil SOC and TN stocks.

\begin{tabular}{lllll}
\hline \multirow{2}{*}{ source of variation } & \multirow{2}{*}{ DF } & SOC stock (T/ha) & \multicolumn{2}{c}{ TN stock (T/ha) } \\
\cline { 2 - 5 } & & MS & P-Value & MS \\
\hline FP & 1 & 625.5 & $<.0001$ & 11.75 \\
D & 2 & 18.1 & 0.0808 & 5.483 \\
FP $\times$ D & 2 & 12.6 & 0.01723 & 0.856 \\
Error & 89 & 56.29 & & 0.0001 \\
\hline
\end{tabular}

DF, Degree of freedom, FP Farming practice, D soil depth, SE standard error of the mean, MS mean square, and SOC soil organic carbon stocks, TN, Total nitrogen stocks.

Such management practices impact improving the soil physicochemical properties and SOC stocks. Furthermore, a low carbon stock in the conventional agriculture has been due to the crop uptake, leaching, and surface erosion losses. The lower TN stocks in the soil depth and across the farming practices were due to the reductions under the conventional system could related to topsoil soil layer, to no input of organic material and to increase topsoil exposure.

A continuous various leguminous crop can explain the presence of high soil nitrogen stocks in the conservation as compared conventional agriculture and crop residue could constitute the lion's share for the high soil OC and total nitrogen stocks conservation agriculture practice.

\section{Conclusion}

The conventional farming practice that involves intensive and continuous cultivation is the cause of the lower SOC stock and other soil physicochemical properties exhibited in the cultivated land without any conservation measures. The lower other selected soil chemical properties concentrations have recorded in conventional farming practices. Furthermore, soils under these conventional farming practices had lower SOC stocks than in the conservation agricultural practice due to crop residues are being grazed, burned or removed and sometimes incorporated by the plough, and intensive tillage and mono cropping; that is causing the soil fertility depletion. The conservation, agricultural practices have influenced the selected soil physicochemical properties and soil carbon stocks. It has enhanced the SOC stock and other selected soil physicochemical properties in conservation agriculture than in the conventional agricultural practice. The soil depth is also influencing these soils physicochemical properties regardless of the farming practices.

Therefore, CA practices improve soil aggregation; reduce bulk density in long run due to carbon pool and improvement of soil structure. The higher amount of SOC in surface soil layer in $\mathrm{CA}$ is due to higher accumulation of crop residue, which also increases the availability of mineral nutrition. Thus, the implementation and adoption of restorative land use. Such as CA practice with appropriate soil management could result in carbon and nitrogen accumulation, stabilization, and sustainable use of soil resources.

\section{References}

[1] Ahmad, N. 1986. Soil and agronomic factors influencing fodder production in the Ethiopian highlands of East Africa. PSD Working paper no. B4. International Livestock Centre for Africa (ILCA), Addis Ababa, Ethiopia. Pp. 58.

[2] Baruah, R., Medhi, B. K., Patgiri, D. K., Bhattacharyya, D. and Deka, C. R., 2017. Soil organic carbon stock in agricultural land of Jorhat district of Assam. Journal of Soil and Water Conservation, 16 (1), pp. 25-31.

[3] Blake, G. R., and Hartge, K. H. 1986. Bulk density in methods of Soil Analysis, Part I: Physical and Mineralogical Methods (Klute, A. eds.); Soil Science Society of America: Madison, Wisconsin, pp. 363-375.

[4] Brady, N. C. and Weil, R. R. 2002. The Nature and Properties of Soils, 13th Ed. Prentice- Hall Inc., New Jersey, USA. 960: pp. 16-27.

[5] Beretta, A. N., Silbermann, A. V., Paladino, L., Torres, D., Bassahun, D., Musselli, R. and García-Lamohte, A., 2014. Soil te $\times$ ture analyses using a hydrometer: modification of the Bouyoucos method. Ciencia e investigación agraria, 41 (2), pp. 263-271.

[6] Chaudhari, P. R., Ahire, D. V., Ahire, V. D., Chkravarty, M. and Maity, S. 2013. Soil bulk density as related to soil texture, organic matter content and available total nutrients of Coimbatore soil. International Journal of Scientific and Research Publications. 3 (2): pp. 1-8.

[7] Chernet, T. Hart, WK. Aronson, JL. and Walter, RC. 1998. New age constraints on the Timing of volcanism and tectonism in the northern Ethiopian Main Rift-Southern Afar transition zone. J. Volcanol. Geotherm. Res., 80: pp. 267-280. 
[8] Dudal, R., 1965. Dark clay soils of tropical and sub-tropical regions. Agricultural Development Report 83. FAO (Food and Agriculture Organization), Rome. pp. 16.

[9] Eggleston, S., Buendia, L., and Miwa, K. 2006. IPCC guidelines for national greenhouse gas inventories (recursoelectrónico): waste. Kanagawa, JP: Institute for Global Environmental Strategies, cultivated soils. Soil Sci. Soc. Am. J. 50: pp. 627-633.

[10] Foth, H. D. and B. G. Ellis., 1997. Soil fertility, 2nd Ed. Lewis CRC Press LLC., USA.

[11] Gicheru, P., Gachene, C., Mbuvi, J. and Mare, E., 2004. Effects of soil management practices and tillage systems on surface soil water conservation and crust formation on a sandy loam in semi-arid Kenya. Soil and Tillage Research, 75 (2), pp. 173-184.

[12] Gustafsson, J., Cederberg, C., Sonesson, U., and Emanuelsson, A. 2013. The methodology of the FAO study: Global Food Losses and Food Waste-e×tent, causes and prevention"-FAO, 2011. SIK Institutet förlivsmedelochbioteknik.

[13] Govaerts, B., Fuentes, M., Sayre, K. D., Mezzalama, M., Nicol, J. M., Deckers, J., Etchevers, J., and Figueroa-Sandoval, B. 2007. Infiltration, soil moisture, root rot and nematode populations after 12 years of different tillage, residue and crop rotation managements. Soil Till. Res. 94: 209-219.

[14] Gwenzi, W., Gotosa, J., Chakanetsa, S. and Mutema, Z., 2009. Effects of tillage systems on soil organic carbon dynamics, structural stability and crop yields in irrigated wheat (Triticum aestivum L.) -cotton (Gossypium hirsutum L.) rotation in semi-arid Zimbabwe. Nutrient Cycling in Agroecosystems, 83 (3), p. 211.

[15] Havlin, J. L., Beaton, J. D., Tisdale, S. L., and Nelson, W. L. 2005. Soil fertility and fertilizers: An introduction to nutrient management. 7th Edition. Pearson Prentice Hall Publishers, Upper Saddle River, New Jersey, USA.

[16] Jat, R. K., Sapkota, T. B., Singh, R. G., Jat, M. L. L., Kumar, M. \& Gupta, R. K. 2014. Seven years of conservation agriculture in a rice-wheat rotation of Eastern Gangetic Plains of South Asia: yield trends and economic profitability. Field Crops Research, 164, 199-210

[17] Jones, J. B. 2003. Agronomic handbook: management of crops, soils, and their fertility. CRC press LLC, N. W. Corporate Blvd., Boca Ratio, Florida.

[18] Karppinen, K., Zoratti, L., Nguyenquynh, N., Häggman, H. and Jaakola, L., 2016. On the developmental and environmental regulation of secondary metabolism in Vaccinium spp. berries. Frontiers in plant science, 7, pp. 655.
[19] Kumar, A., Somasundaram, J., Biswas, A. K., Sinha, N. K., Mishra, V. N., Chaudhary, R. S., Mohanty, M., Hati, K. M., Saha, R. and Patra, A. K., 2017. Short-term effect of conservation agriculture practices on soil quality of a vertisol in central India. Applied Biological Research, 19 (1), pp. 2634

[20] Leifeld. J, S. Bassin, and J. Fuhrer, 2005. Carbon stocks in Swiss agricultural soils predicted by land-use, soil characteristics, and altitude, Agr. Ecosyst. Environ., 105, pp. 255-266.

[21] Mann, W., Henderson, B., Branca, G., Lipper, L., Gerber, P., Tennigkeit, T., Neves, B. and Wilkes, A., 2011. Climate change mitigation finance for smallholder agriculture: a guide book to harvesting soil carbon sequestration benefits.

[22] Mengistu C, Kibebew K, Tarekegn F. 2017. Influence of Different Land Use Types and Soil Depths on Selected Soil Properties Related to Soil Fertility in Warandhab Area, Horo Guduru Wallaga Zone, Oromiya, Ethiopia. Int J Environ Sci Nat Res., 4 (2): 555634.

[23] McGarry, D., Bridge, B. J. and Radford, B. J. 2000. Contrasting soil physical properties after zero and traditional tillage of an alluvial soil in the semi-arid subtropical. Soil Tillage Research 53 (2), pp 105-115.

[24] Morisada, K., Ono, K., and Kanomata, H. 2004. Organic carbon stock in forest soils in Japan. Geoderma, 119 (1-2), pp. 21-32.

[25] Muche M, Kokeb A, Molla E, 2005. Assessing the Physicochemical Properties of Soil under Different Land Use Types. J Environ Anal To×icol.; 5: 309

[26] Murphy, B. 2014. Soil organic matter and soil functionReview of the literature and underlying data. Department of the environment, canberra, Australia. pp. 155.

[27] Negassa, W., Abera, T., Friesen, D. K., Deressa, A. and Dinsa, B., 2001, February. Evaluation of compost for maize production under farmers' conditions. In Seventh Eastern and Southern Africa Regional Maize Conference (pp. 382-386).

[28] Rice, C. and Scholes, B., 2008. Greenhouse gas mitigation in agriculture. Philosophical Transactions of the Royal Society of London B: Biological Sciences, 363 (1492), pp. 789-813

[29] Smith, P., Martino, D., Cai, Z., Gwary, D., Janzen, H., Kumar, P., McCarl, B., Ogle, S., O'Mara, F., Rice, C. and Scholes, B., 2007. Greenhouse gas mitigation in agriculture. Philosophical transactions of the royal Society B: Biological Sciences, 363 (1492), pp. 789-813. 